\title{
INTERFERON BETA-1A TREATMENT IN HTLV-1-ASSOCIATED MYELOPATHY/TROPICAL SPASTIC PARAPARESIS: A CASE REPORT
}

Graça Maria de Castro VIANA(1), Marcos Antonio Custódio Neto da SILVA(2), Victor Lima SOUZA(2), Natália Barbosa da Silva LOPES(2), Diego Luz Felipe da SILVA(2) \& Maria do Desterro Soares Brandão NASCIMENTO(1)

\begin{abstract}
SUMMARY
Here a young patient $(<21$ years of age) with a history of infective dermatitis is described. The patient was diagnosed with myelopathy associated with HTLV-1/tropical spastic paraparesis and treated with interferon beta-1a. The disease was clinically established as HTLV-1-associated myelopathy/tropical spastic paraparesis (HAM/TSP), and laboratory tests confirmed the presence of antibodies to HTLV-1 in the cerebrospinal fluid (CSF). Mumps, cytomegalovirus, Epstein-Barr virus, schistosomiasis, herpes virus 1 and 2, rubella, measles, varicella-zoster toxoplasmosis, hepatitis, HIV, and syphilis were excluded by serology. The patient was diagnosed with neurogenic bladder and presented with nocturia, urinary urgency, paresthesia of the lower left limb, a marked reduction of muscle strength in the lower limbs, and a slight reduction in upper limb strength. During the fourth week of treatment with interferon beta-1a, urinary urgency and paresthesia disappeared and clinical motor skills improved.
\end{abstract}

KEYWORDS: HAM/TSP; HTLV-1; Interferon beta-1a; Treatment.

\section{INTRODUCTION}

The human T-lymphotropic virus (HTLV) is a retrovirus belonging to the Retroviridae family. HTLV can infect cells of the human immune system and has tropism for T-lymphocytes ${ }^{14,15}$ (T-cells). Approximately 10-20 million people worldwide are infected with HTLV-1, which is considered a global epidemic. HTLV-1 is associated with a wide spectrum of manifestations including tropical spastic paraparesis, a disease characterized by the slow and progressive development of myelopathy, as well as leukemia/lymphoma in adult T-cells ${ }^{6}$. HTLV-1 is endemic in many regions of the world, more common in adult women, and usually insidious, but may be sudden. There is a high prevalence of HTLV-1 in southern Japan, the Caribbean, Africa, South America, Papua New Guinea, the Middle East, Australia, and Southeast Italy ${ }^{11}$. In Brazil, HTLV-1 is found in several states, but is more prevalent in certain regions, such as in the Northeast, particularly Maranhão, where the prevalence is 10 per 1000 blood donors $^{3}$.

HTLV-1-associated myelopathy/tropical spastic paraparesis (HAM/ TSP) is a demyelinating disease with inflammatory changes in the central nervous system. HTLV-1 is predominantly transmitted via blood; however, vertical and sexual transmission is also possible ${ }^{12}$. HAM/TSP is characterized by neurological manifestations, such as chronic spastic paraparesis, impaired gait, and weakness in the lower limbs. Other symptoms include sphincter signs and symptoms such as bladder disorders (urinary urge incontinence and nocturia) and sensory symptoms including paresthesia, hyperreflexia of the lower limbs, and the presence of the Babinski signal often with clonus (signs of pyramidal release). Laboratory diagnosis is made by the identification of HTLV$1 / 2$ antibodies in the blood and cerebrospinal fluid (CSF). Results are confirmed by Western blot or detection of proviral DNA in the blood or $\mathrm{CSF}^{12}$.

In this study, a patient with HAM/TSP treated with interferon beta-1a was presented, with a good outcome.

\section{CASE REPORT}

A 21-year-old widowed female patient, with a history of infective dermatitis in childhood reported, decreased muscle strength in the upper and lower limbs, particularly on the right side. The patient was seen as a referral to the rehabilitation department. She was diagnosed with HTLV-1-associated myelopathy/tropical spastic paraparesis, confirmed by positive levels of HTLV in serum (ELISA: 3.15, Cut-Off: 0.18) and the CSF (ELISA: 2.57, Cut-Off: 0.18). Additionally, anti-HTLV confirmation was made using Western blot analyses.

The referral hospital also identified antibodies in the CSF and excluded mumps, cytomegalovirus, Epstein-Barr virus, schistosomiasis, herpes virus 1 and 2, rubella, measles, toxoplasmosis, and varicella-zoster

(1) Departamento de Patologia, Universidade Federal do Maranhão, São Luis, MA, Brazil. E-mails: gracaviana@globo.com, cnsd_ma@uol.com.br

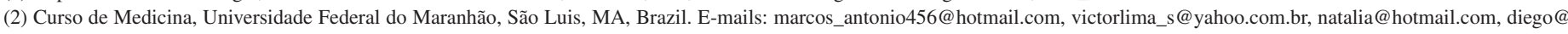
hotmail.com

Correspondence to: Graça Maria de Castro Viana, Praça Madre Deus 1, Madre Deus, São Luis, MA, Brasil. E-mail: gracaviana@globo.com 


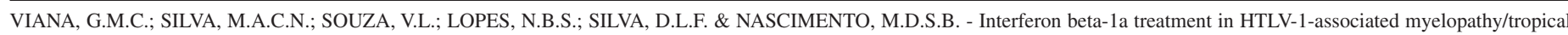
spastic paraparesis: a case report. Rev. Inst. Med. Trop. Sao Paulo, 56(5): 443-5, 2014.

virus. Serology for hepatitis, syphilis and HIV were also negative. Protein electrophoresis showed albumin values of $15.6 \mathrm{mg} / \mathrm{dL}$ (normal range: $5.6-45.6 \mathrm{mg} / \mathrm{dL}$ ), beta-globulin values of $5.7 \mathrm{mg} / \mathrm{dL}$ (normal range: $0.8-10.8 \mathrm{mg} / \mathrm{dL}$ ), and gamma-globulin values of $7.2 \mathrm{mg} / \mathrm{dL}$ (normal range: $0.3-7.2 \mathrm{mg} / \mathrm{dL})$. The complete blood count (CBC) was 3.09 million red blood cells (RBCs) $/ \mathrm{mm}^{3}, 9.4 \mathrm{~g} / \mathrm{dL}$ hemoglobin, hematocrit $29 \%$, lymphocytes $41 \%$, erythrocyte sedimentation rate (ESR) of $40 \mathrm{~mm}$ in the first hour, and 192,000 platelets.

A differential diagnosis for demyelinating disease and lupus was performed. Lupus and demyelinating disease were ruled out by clinical presentation and laboratory tests for lupus (anticoagulant, anticardiolipin IgG and IgM, and anti-DNA antibodies, all negatives). The serology of the patient's mother could not be assessed, because she refused testing. The patient's husband was also not tested, because he died before the onset of her clinical manifestations. However, the patient has a daughter (aged two years) who was seropositive for HTLV-1.

One year prior to diagnosis of HTLV-1, the patient was diagnosed with neurogenic bladder, with clinical nocturia ( four times per night), urinary urgency, severe loss of muscle strength in the lower limbs, positive Babinski reflex and paresthesia in the left leg. The patient had also started walking with support on the right side. The patient could walk $10 \mathrm{~m}$ in $12 \mathrm{~s}$.

Interferon beta- 1 a treatment $(3,000,000$ IU) was started three times a week for 10 weeks. Clinical evaluations were performed after four weeks of therapy. Improvement was first observed in sensory manifestations followed by motor evaluation. The patient showed improvements in muscle strength and nocturia (reduced to once per night) with the disappearance of urinary urgency and paresthesia. The patient's gait became more agile and quick, and she could walk $10 \mathrm{~m}$ in $10 \mathrm{~s}$. Two years after completing treatment, the patient still reports improved clinical sensory and motor skills.

\section{DISCUSSION}

HTLV-1/2 infection is endemic in Brazil ${ }^{4}$ where $5 \%$ of people are seropositive. There is a high incidence in Maranhão, where 10 per 1000 blood donors are seropositive ${ }^{3}$. HTLV-1/2 is more frequent among women ${ }^{10}$ in the fourth and fifth decade of life ${ }^{5}$, contrary to the age of the patient in this study and the data provided by CARVALHO et al. (2009) ${ }^{2}$.

Several promising therapies have been considered and evaluated for HAM/TSP, although none have been approved for use in patients yet.

The treatment of HTLV-1-associated myelopathy/tropical spastic paraparesis can be divided into specific and symptomatic cases. Specific immunosuppressive drugs (corticosteroids) and/or immunomodulators (interferon alpha and beta-1) are used for treatment. These drugs work to inhibit T-lymphocyte activation, which modulates leukocyte migration and minimizes the production of inflammatory cytokines. There are drugs for symptomatic treatment that can control pain, neurogenic bladder, constipation, and spasticity ${ }^{1}$.

Studies using interferon alpha to treat patients with HAM/TSP have shown better clinical outcomes and reduced proviral loads ${ }^{8,13,16}$.
Interferon beta-1a has been used to treat relapsing-remitting multiple sclerosis and has been shown to be beneficial in several trials ${ }^{7,10}$. In HAM/ TSP, only two studies evaluated interferon beta-1a treatment. One study used a dose of 60 mcg twice per week, which reduced tax-CD8+ cells, but did not reduce the proviral DNA load ${ }^{9}$. The other study used a lower dose of 30 mcg every 15 days and noted good outcomes ${ }^{4}$.

In this study, it was chosen to treat with interferon beta-1a instead of interferon alpha, because the latter has a daily dosage schedule rather than the simple weekly interferon beta-1a dosage.

Treatment with interferon beta-1a $(3,000,000 \mathrm{IU})$ three times a week for 10 weeks improved the urinary and motor symptoms of the patient. Although interferon beta-1a may not be the standard treatment for HTLV-1-associated myelopathy/tropical spastic paraparesis, in this case it proved to be very promising. This underscores the need for more clinical studies using interferon beta-1a.

\section{RESUMO}

\section{Tratamento com interferon beta-1a em mielopatia associada ao HTLV-1/paraparesia espástica tropical: relato de caso}

Descreve-se caso de mielopatia associada ao HTLV-1/paraparesia espástica tropical tratada com interferon beta-1a em paciente jovem de 21 anos e com história de dermatite infecciosa na infância. Foi estabelecida clinicamente paraparesia espástica tropical (HAM/TSP), confirmada laboratorialmente pela presença de anticorpos para HTLV-1 no LCR e excluídas caxumba, citomegalovirus, Epstein-Barr, esquistossomose, herpes virus 1 e 2, rubéola, sarampo, toxoplasmose varicela-zoster, hepatite, HIV e sífilis por sorologias. Foi diagnosticada bexiga neurogênica, com quadro clínico de nictúria, urgência urinária, parestesia no membro inferior esquerdo e discreta redução de força muscular nos membros superiores, mais acentuada nos membros inferiores. $\mathrm{Na} 4^{\mathrm{a}}$ semana de tratamento com interferon beta-1a houve desaparecimento da urgência urinária e da parestesia e melhora da clínica motora.

\section{REFERENCES}

1. Araújo A, Lima MA, Silva MTT. Avanços e perspectivas na terapêutica das doenças associadas à infecção por HTLV. In: Proietti ABFC, editor. Cadernos Hemominas HTLV. $4^{\mathrm{a}}$ ed. Belo Horizonte: Fundação Hemominas; 2006. p. 228-35.

2. Carvalho AGJ, Galvão-Phileto AV, Lima NS, Jesus RS, Galvão-Castro B, Lima MGL. Frequency of mental disturbances in HTLV-1 patients in the state of Bahia, Brazil. Braz J Infect Dis. 2009;13:5-8.

3. Catalan-Soares B, Carneiro-Proietti ABF, Proetti FA, Interdisciplinary HTLV Research Group. Heterogeneous geographic distribution of human T-cell lymphotropic viruses I and II (HTLV I/II): serological screening prevalence rates in blood donors from large urban areas in Brazil. Cad Saúde Pública. 2005;21:926-31

4. Costa DT, Sundberg M, Passos L, Muniz AL, Santos S. Interferon beta-1a improves urinary symptoms, reduces proviral load, and modifies the immune response in a patient with HAM/TSP. Case Rep Neurol Med. 2012;2012:1-3.

5. Gaspar-Sobrinho FP, Souza-Machado A, Santos SB, Orge G, Lessa HA, Cruz AA, et al. Clinical and immunological features of patients with atopy and concomitant HLTV-1 infection. Braz J Med Biol Res. 2010;43:1167-72.

6. Gonçalves CCA, Ribeiro LCP, Sá CAM, Puccioni-Sohler M. Diagnóstico laboratorial da mielopatia associada ao HTLV-I: métodos para análise do líquido cefalorraquidiano. J Bras Patol Med Lab. 2009;45:99-110. 


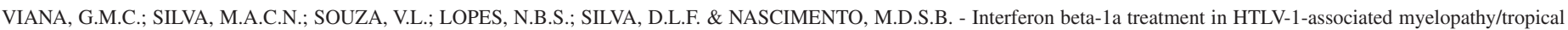
spastic paraparesis: a case report. Rev. Inst. Med. Trop. Sao Paulo, 56(5): 443-5, 2014.

7. Jacobs LD, Cookfair DL, Rudick RA, Herndon RM, Richert JR, Salazar AM, et al. Intramuscular interferon beta-1a for disease progression in relapsing multiple sclerosis. The Multiple Sclerosis Collaborative Research Group (MSCRG). Ann Neurol. 1996;39:285-94.

8. Kuroda Y, Kurohara K, Fujiyama F, Takashima H, Endo C, Matsui M, et al. Systemic interferon-alpha in the treatment of HTLV-I-associated myelopathy. Acta Neurol Scand. 1992;86:82-6.

9. Oh U, Yamano Y, Mora CA, Ohayon J, Bagnato F, Butman JA, et al. Interferon- $\beta 1$ a therapy in human T-lymphotropic virus type I-associated neurologic disease. Ann Neurol. 2005;57:526-34

10. Randomised double-blind placebo-controlled study of interferon beta-1a in relapsing/ remitting multiple sclerosis. PRISMS (Prevention of Relapses and Disability by Interferon beta-1a Subcutaneously in Multiple Sclerosis) Study Group. Lancet. 1998;352(9139):1498-504.

11. Rêgo A, Feitosa F, Cavalcante D, Paraná R. VHC e HTLV-I: aspectos clínicos e epidemiológicos da co-infecção. Rev Cienc Méd Biol (Salvador). 2003;2:230-9.

12. Ribas JGR, Melo GCN. Mielopatia associada ao vírus linfotrópico humano de células T do tipo 1 (HTLV-1). Rev Soc Bras Med Trop. 2002;35:377-84.
13. Saito M, Nakagawa M, Kaseda S, Matsuzaki T, Jonosono M, Eiraku N, et al. Decreased human T lymphotropic virus type I (HTLV-I) provirus load and alteration in T cell phenotype after interferon-alpha therapy for HTLV-I associated myelopathy/tropical spastic paraparesis. J Infect Dis. 2004;189:29-40.

14. Santos FLN, Lima FWM. Epidemiologia, fisiopatogenia e diagnóstico laboratorial da infecção pelo HTLV-I. J Bras Patol Med Lab. 2005;41:105-16.

15. Santos NSO, Wigg MD, Oliveira DP. Viroses multissistêmicas. In: Santos NSO Romanos MTV, Wigg MD, editores. Introdução à virologia humana. $2^{\mathrm{a}}$ ed. Rio de Janeiro: Guanabara Koogan; 2008. p. 290-330.

16. Yamasaki K, Kira J, Koyanagi Y, Kawano Y, Miyano-Kurosaki N, Nakamura M, et al. Long term, high dose interferon-alpha treatment in HTLV-I-associated myelopathy/ tropical spastic paraparesis: a combined clinical, virological and immunological study. J Neurol Sci. 1997;147:135-44

Received: 8 August 2013

Accepted: 18 February 2014 